\title{
DEVELOPING CONSTITUTIONAL RIGHTS OF, IN, AND FOR CHILDREN*
}

\begin{abstract}
ROBERT A. BURT $\dagger$
The Supreme Court has in recent years decided many cases challenging state substitute-parenting activities. The increasing number of such cases on the recent Supreme Court docket is itself a striking fact, most likely reflecting the Court's perception of widespread concern about family structure in the society. Taken together, these decisions appear to vest constitutional rights in both parents and children against state interventions and increasingly to curtail state authority to intervene against parental wishes on behalf of children. But the Court has not yet formulated a coherent rationale for this stance, nor has it acknowledged that its application of constitutional norms in these cases yields some generalizations about the permissible scope of state substitute-parenting activities.

This discussion will address that task. It will not consider state interventions to control juveniles who commit overtly antisocial acts. In principle, the justifications for such state interventions are clear. In practice, the obstacles to successful interventions seem the same as for adult corrections. Instead, the focus will be on state efforts exclusively intended (in the catchphrase) to help troubled children rather than to punish children in trouble.
\end{abstract}

\section{I}

Supreme Court decisions proclaiming rights of both parents and children to be free from state substitute-parenting have followed converging paths. Wisconsin $v$. Yoder ${ }^{1}$ is perhaps the most dramatic of the recent "parents' rights" decisions. In that case, the Court upheld claims of Amish parents to exempt their children from state compulsory education laws following eighth-grade schooling. The Court rested its conclusion on intertwined principles of religious freedom and parental prerogatives and suggested that parental claims that lacked an explicit religious content would command less deference. ${ }^{2}$

* 1976 by the author. This article will appear in a forthcoming volume of essays, tentatively entitled Pursuing Justice for the Child, edited by Margaret K. Rosenheim, to be published by the University of Chicago Press. The author has been particularly helped in this article by the comments and criticisms of Francis A. Allen, Stephen R. Goldstein, Jay Katz, Terrance Sandalow, and Peter L. Strauss.

†Professor of Law and Professor of Law in Psychiatry, University of Michigan.

1. 406 U.S. 205 (1972).

2. Id. at 235-36. 
Yoder's application of the religion clause of the first amendment is, however, vulnerable to doctrinal criticism. Notwithstanding the Court's contrary assertions, its ruling appears difficult to square with its recent decisions invalidating-for allegedly "establishing" state-favored religions-laws that assisted parents in sending their children to church-related rather than public schools. ${ }^{3}$ But bypassing this objection, there is powerful good sense to the Court's result. Amish parents had a passionate belief that secondary schooling would expose their children to "modern" and "sinful" pursuits. The Court stated: ${ }^{4}$

[M]odern compulsory secondary education in rural areas is now largely carried on in a consolidated school, often remote from the student's home and alien to his daily home life. As the record so strongly shows, the values and programs of the modern secondary school are in sharp conflict with the fundamental mode of life mandated by the Amish religion ... [and such school] carries with it a very real threat of undermining the Amish community and religious practice as they exist today ....

The state's justification for overriding the intense convictions of the Amish parents appears unpersuasive. It may be that Wisconsin school authorities appreciated the psychological stress-and even possible developmental risks-that might be caused by forcing children into social settings that their parents saw as irredeemably sinful. But no such understanding was evident in the case record. The Court noted that the state school superintendent rejected a proposal offered by the Amish-one that had been adopted in several other states with Amish populations-that their children attend locally organized secondary schools with special curricula. The ostensible ground for the rejection was that such arrangement "would not afford Amish children 'substantially equivalent education' to that offered in the schools of the area." 5 This attitude appears to ignore the clear fact that Amish children were not "substantially equivalent" to most school children in Wisconsin and that differences in rearing and parental attitudes might require a different educational response.

This is not to say that there was an easy answer to the question whether Amish children should be exempted from compulsory secondary schooling. The choice between avowedly preparing Amish children only for the circumscribed world of their parents or for entry into the more common community raises complex value questions. But if the state were prepared to act so dramatically against parental views, it should have acted with careful sensitivity to the conflicts thus imposed on the Amish children, or state action would have had no reliable utility for them. As the state portrayed its

3. See Committee for Pub. Educ. \& Religious Liberty v. Nyquist, 413 U.S. 756 (1973); Sloan v. Lemon, 413 U.S. 825 (1973).

4. 406 U.S. at $217-18$.

5. Id. at 209 n.3. 
purposes in the litigation, however, the special needs of these children seemed to be subordinated to the state's intention to do battle for Enlightenment against the Forces of Darkness.

This is a common characteristic of state interventions against parents purportedly on behalf of children-a generalized attitude of self-righteousness, even punitiveness, toward "difficult" parents that takes little account of the individual needs of the affected child. This trait is as evident-and as harmful to children-in state interventions to rescue physically abused children from their parents as in state efforts to save the less obviously needy Amish children. ${ }^{6}$

The point can be underscored by considering a 1944 Supreme Court decision, Prince v. Massachusetts, ${ }^{7}$ which upheld application to a Jehovah's Witness family of a state law banning street solicitation by children. Justice Rutledge wrote the Court's opinion in Prince, and his statement of the facts gives the full flavor of his sympathies for the parent and for the passionate desire of the child to model herself after her parent: ${ }^{8}$

[Mrs. Prince] was accustomed to go each week on the streets of Brockton to distribute "Watchtower" and "Consolation" UJehovah's Witnesses' publications] ... . She had permitted the children to engage in this activity previously, and had been warned against doing so by the school attendance officer, Mr. Perkins. But, until December 18, 1941, she generally did not take them with her at night.

That evening, as Mrs. Prince was preparing to leave her home, the children asked to go. She at first refused. Childlike, they resorted to tears; and, motherlike, she yielded. Arriving downtown, Mrs. Prince permitted the children "to engage in the preaching work with her upon the sidewalks." That is, with specific reference to [nine-year-old] Betty, she and Mrs. Prince took positions about twenty feet apart near a street intersection. Betty held up in her hand, for passers-by to see, copies of "Watch Tower" and "Consolation." From her shoulder hung the usual canvas magazine bag, on which was printed, "Watchtower and Consolation $5 x$ per copy."

Mrs. Prince and Betty remained until 8:45 p.m. A few minutes before this, Mr. Perkins approached Mrs. Prince. . . Mrs. Prince admitted she supplied Betty with the magazines and said, "[N]either you nor anybody else can stop me.... This child is exercising her God-given right and her constitutional right to preach the gospel, and no creature has a right to interfere with God's commands." . . . [T] ] stimony, by Betty, [Mrs. Prince] and others, was offered at the trials, and was excluded, to show that Betty believed it was her religious duty to perform this work and failure would bring condemnation "to everlasting destruction at Armageddon."

6. See Burt, Forcing Protection on Children and Their Parents: The Impact of Wyman v. James, 69 Mich. L. REv. 1259, 1278-81 (1971).

7. 321 U.S. $158(1944)$.

8. Id. at $161-63$. 
Yet, notwithstanding this sympathetic portrayal of the family relationship in religious pursuit, the Court upheld Mrs. Prince's conviction. In language clearly applicable, though not applied, to the Amish in Yoder, Justice Rutledge stated: ${ }^{9}$

The state's authority over children's activities is broader than over like actions of adults. . . . The zealous though lawful exercise of the right to engage in propagandizing the community, whether in religious, political or other matters, may and at times does create situations difficult enough for adults to cope with and wholly inappropriate for children, especially of tender years, to face. Other harmful possibilities could be stated, of emotional excitement and psychological or physical injury. Parents may be free to become martyrs themselves. But it does not follow they are free, in identical circumstances, to make martyrs of their children before they have reached the age of full and legal discretion when they can make that choice for themselves.

Just as the Amish parents asked only a limited exemption for their children past the eighth grade, Mrs. Prince invited the Court to exempt children for religiously motivated street sales only under direct parental supervision. ${ }^{10}$ The same psychological virtues were evident in Prince that the Yoder Court praised in Amish child rearing practice-particularly the involvement of young children in productive work-learning relationships with their parents, thus avoiding the rigid age segregations endemic in our society. The state policy in Prince was-even more than in Yoder-unbending, overtly disdainful of parental values, and inattentive to the passionately expressed desires of the affected children. A further aspect of Prince has special contemporary significance, readily overlooked in 1944. Mrs. Prince was accompanied on her expedition by not only Betty, but her two sons. The state brought no prosecution on their account. Though the sons' ages do not appear in the available record, it is plausible to assume that they were saved by a sexist differentiation in state law proscribing street sales by boys under twelve and by girls under eighteen. ${ }^{11}$

Prince has been considered at length not simply to suggest that it cannot be reconciled with nor that it better withstands constitutional doctrinal analysis than Yoder. Rather, more importantly for present purposes, both cases illustrate that even if parents seem to be using children for their own ends, state intervention typically has little better to offer. The battle between state and parent in these cases seems remarkably like typical divorce custody disputes, in which neither arult seems incontestably correct, and

9. Id. at $168-70$.

10. Id. at 169 .

11. See id. at $160-61$. 
each seems locked in a power struggle with the other, using the child as weapon and trophy while ignoring his needs. ${ }^{12}$

This same analysis can be applied to recent Supreme Court decisions purporting to establish "rights of children" against state intervention without explicit reference to parental views. In Tinker \%. Des Moines Independent Community School District, ${ }^{13}$ the Court ruled that public schools could not discipline students for wearing black armbands to protest the Vietnam War. The plaintiffs were two children from the Tinker family, thirteen and fifteen years old, and a sixteen-year-old friend, Christopher Eckhardt. Justice Fortas, for the Court, resoundingly proclaimed that "students in school as well as out of school are 'persons' under our Constitution. They are possessed of fundamental rights which the State must respect . . .."14

The Court did not mention, however, that two other children from the Tinker family (though not plaintiffs in the case) had also worn black armbands to school. These children were eight and eleven years old. ${ }^{15}$ Perhaps tactical reasons led to the exclusion of these children from the suit. It does, indeed, seem incongruous to unfurl the first amendment for the right of eight-year-olds to protest their government's war policy. Further, the Court described, without any irony apparently intended, the way in which the plaintiff children decided to wear their armbands: ${ }^{16}$

In December 1965, a group of adults and students in Des Moines held a meeting at the Eckhardt home. The group determined to publicize their objections to the hostilities in Vietnam and their support for a truce by wearing black armbands during the holiday season and by fasting on December 16 and New Year's Eve. [Plaintiffs'] parents had previously engaged in similar activities, and they decided to participate in the program.

Justice Black, in dissent, noted that the Tinker children's father was "a Methodist minister without a church ... paid a salary by the American Friends Service Committee" and that Christopher Eckhardt's mother was "an official in the Women's International League for Peace and Freedom." "17 From this record, is it crystal clear whose political expression rights were being protected-the children's or their parents'? Is it clear that Justice Rutledge's concern in Prince has no place here, that "propagandizing the community

12. See, e.g., Watson, The Children of Armageddon: Problems of Custody Following Divorce, 21 Syracuse L. ReV. 55, 59-61 (1969).

13. 393 U.S. 503 (1969).

14. Id. at 511 .

15. Id. at 516 (Black, J, dissenting).

16. Id. at 504 .

17. $\quad l d$. at 516 . 
. . . create[s] situations difficult enough for adults," and that parents are not "free . . to make martyrs of their children"? 18

Tinker, from this perspective, is no different from the parental-rights cases considered earlier. In general, it is false psychology to portray a dispute between children and the state without acknowledging the direct-implicit or explicit-role of parents in that dispute. ${ }^{19}$ But Tinker, further considered, suggests reasons why the Court was correct to favor the parents' position in all of the cases discussed thus far. Or, to put the matter somewhat differently, Tinker suggests why the Court could properly ignore the possibility that the children were not autonomous actors in these cases and that, in fact, their parents were significantly interfering with their autonomy.

The state's error appears in the Court's narrative as follows: ${ }^{20}$

The principals of the Des Moines schools became aware of the plan to wear armbands. On December 14, 1965, they met and adopted a policy that any student wearing an armband to school would be asked to remove it, and if he refused he would be suspended until he returned without the armband .... On December 16, Mary Beth and Christopher wore black armbands to their schools. John Tinker wore his armband the next day. They were all sent home and suspended from school until they would come back without their armbands. They did not return to school until after the planned period for wearing armbands had expired-that is, until after New Year's Day.

The Court also noted that the December 14 school principals' meeting was originally called after a student told his journalism teacher that "he wanted to write an article on Vietnam and have it published in the school paper." 21 Following this meeting, school authorities dissuaded the student from that action. ${ }^{22}$ The Court also observed that "the school authorities did not purport to prohibit the wearing of all symbols of political or controversial significance." ${ }^{33}$ Further, if the goal of the school was to bolster students' independence from their parents' political viewpoints, suspension from school and forced return home seems a strange instrument for that purpose.

Even if Tinker is-as Yoder and Prince may be-a symbolic battle between adults, each using children as sacrificial pawns, the Constitution clearly constrains the state more than parents in this matter. If the Des Moines school officials, that is, insist on one brand of ideological conformity, the traditions of the first amendment amply justify a court ruling that this is impermissible state action in itself.

18. 321 U.S. at 169-70.

19. See, e.g., A. Freud, Normality and Pathology in Childhood 43, 46 (1965); A. Freud, The Psychoanalytical Treatient of Childrex 9 - 10 (1964).

20. 393 U.S. at 504 .

21. Id. at 510 .

22. $I d$.

23. Id. 
The Tinker Court erred not in its result, but in its failure to acknowledge the potential educational and constitutional relevance of the facts in the case suggesting that the children's armbands reflected more their parents' convictions than theirs. The Court ignored the possibility that school officials might exclude parental political views from school in order to free children to think through these questions for themselves. As noted, that motivation was implausible on the face of the Tinker record, but it is not an implausible educational goal, nor should that goal be prohibited by the Constitution. The Tinker Court should have acknowledged that the constitutional question would have changed complexion if the school officials had convincingly argued that they were acting not to impose their political views on students, but rather on behalf of the root values of the first amendmenttolerance, diversity of thought, individual autonomy-against parental impositions on children.

\section{III}

Commitment to individual autonomy is, of course, an ideology. But it is deeply a part of the American ethos. In extolling the virtues of the tightly conformist Amish society, the Yoder Court betrayed intellectual confusion by linking the parents' claims over their children with American individualistic traditions. The Court noted "the Amish qualities of reliability, self-reliance, and dedication to work" ${ }^{24}$ and asserted that ${ }^{25}$

the Amish communities singularly parallel and reflect many of the virtues of Jefferson's ideal of the "sturdy yeoman" who would form the basis . . of a democratic society. Even their idiosyncratic separateness exemplifies the diversity we profess to admire and encourage.

The Court was apparently not troubled by-or perhaps not aware of-the rigid intolerance of dissent reported among adult members of the Amish community. ${ }^{26}$ It might surprise Jefferson or Thoreau to learn that a twentiethcentury court found individualistic values incarnate in the Amish community.

24. 406 U.S. at 224 .

25. $I d$. at $225-26$.

26. Dr. John Hostetler, who testified at the Yoder trial and whose work was cited throughout the Court's opinion, $i d$. at 209 n.3, 210 n.5, 212, 217 n.8, 225 n.13, has described the practice of "excommunication and shunning" in Amish communities:

It is their primary concern to keep their own baptized members from slipping into the outer world, or into other religious groups. With greater mobility and ease of travel and communication, isolation is breaking down, and Amish solidarity is threatened by more and more of their members wanting to become like outsiders. The Amish leaders meet this threat with the ban. Members who wish to have automobiles, radios, or the usual comforts of modern living, face the threat of being excommunicated and shunned. Thus the ban is used as an instrument of discipline, not only for the drunkard or the adulterer, but for the person who transgresses the order of the church. It is a powerful instrument....

... 
The Yoder Court seized one aspect of our traditional commitment to selfdetermination in its celebration of the virtues of ethnic pluralism. But the Court appeared to view this pluralism as an end in itself. The matter is, in fact, more complex. American cultural history yields no simple answer to the question whether small-group pluralism is more friend than enemy to the values of individual autonomy and self-determination. The continuing debate can be seen, for just one example, in our historic ambivalence toward small rural communities: do they more embody the hearty virtues of Our Town or the stifling philistinism of Main Street? The Yoder school officials could plausibly claim that Amish community self-determination is at war with the possibility that Amish children would develop toward autonomous individualism, that such individualistic values are highly prized throughout this society, and that small-group pluralism commands deference in our tradition only when it serves instrumentally toward strengthening individualistic character traits alien to the Amish.

At heart, the state's claim for all of its substitute-parenting authority has traditionally rested on an assertion that important social values would be served if the state helped children toward self-reliant autonomy. The Court's skepticism of this claim has been given fullest expression in In re Gault, ${ }^{27}$ which forced formalization of juvenile court procedures explicitly because that court system had, in fact, failed to provide its promised individualized helpful treatment to its charges. But Gault's mandated procedures can, for the most part, be seen as an attempt by the Court to produce a more precise fit between the purposes and the actions of the juvenile court by improving its fact-finding capacity. ${ }^{28} \mathrm{Gault}$, as such, does not proclaim that the state has no authority to pursue its beneficent purposes under any circumstances.

Yoder and Tinker appear to go somewhat beyond this-to limit the purposes that the state may pursue in displacing parental authority over children. And Yoder, in particular, raises doubt about authority for state intervention against contrary parental wishes, even if that intervention might reliably foster a child's autonomy. Thus, the Yoder Court hypothesized that Amish parents might in the future be shown to "prevent . . . their minor children from attending high school despite their expressed desires to the contrary." 29 The Court then continued: ${ }^{30}$

Once an individual is in [this] state . . members are to receive no favors from him.

In a very real sense he is "an outcast, rejected of God and man. His only hope is not

to die before he should be reinstated, lest he should be an outcast also in the world to come."

J. Hostetler, Amish Society 63-65 (rev. ed. 1968).

27. 387 U.S. 1 (1967).

28. See Burt, supra note 6 , at 1293 .

29. 406 U.S. at 231.

30. Id. at 231-32. 
Recognition of the claim of the State in such a proceeding would, of course, call into question traditional concepts of parental control over the religious upbringing and education of their minor children recognized in this Court's past decisions. It is clear that such an intrusion by a State into family decisions in the area of religious training would give rise to grave questions of religious freedom comparable to those raised here .... On this record we neither reach nor decide those issues.

This considerable deference to parental prerogatives appears to rest on two questionable premises. The first, explicitly stated by the Court, is that this dispute between the Amish and the state "is not one in which any harm to the physical or mental health of the child or to the public safety, peace, order, or welfare has been demonstrated or may be properly inferred." ${ }^{31}$ The Court here cited cases, inferentially drawing a contrast, that overrode parents' religiously-based refusals for vaccination or blood transfusions. It is, of course, true that the children's lives or the health of others was not so directly imperiled by the Amish parents in Yoder. But surely it is overstatedor at least question-begging-to assert that no harm at all to the "mental health of the child . . may be properly inferred" from the Yoder record. Norms of mental health are necessarily culturally derived-none more so than the socially-prized adult capacity of autonomous self-determination. Autonomy in a democratic society might be defined as an adult's capacity to choose what his parents might not have chosen for him or for themselves. ${ }^{32}$ Such a norm of mental health is at least inferentially at risk in the Yoder record.

The second questionable premise underlying the Court's deferential attitude toward parents is its implicit conclusion that a state claim to support a child's "expressed desires . . . [to defy his parents would be] an intrusion by a State into family decision," ${ }^{33}$ while the absence of such state intervention would not be an intrusion. But so long as state laws force a child to remain in his parents' custody and demand that all others who deal with him first gain parental consent, ${ }^{34}$ the state has equally intruded into family decisions. It is, thus, question-begging for the Court to assume that the only permissible state intrusion into family life is to support parents against their children. Carrying this argument one step further, if the state does have authority to intervene on behalf of parents, it must also have authority to decide when public purposes would not be served by such intervention. All this authority must be exercised in compliance with constitutional norms, of course. But if the state can mount a case that support of parental prerogatives will disserve a value central to our democratic ethos-that is, individual self-determi-

31. Id. at 230 .

32. See E. Erikson, Childhood and Society 286 (2d ed. 1963).

33. 406 U.S. at 231 .

34. See, e.g., H. Clark, The Law of Domestic Relations in the United States 151 (1968);

Foster \& Freed, A Bill of Rights for Children, 6 FAMiLY L.Q. 343, 358-64 (1972). 
nation-a court would be hard put to assert that some contrary constitutional principle forces deference to parents.

But this is a quarrel with the Yoder opinion, not with its result. The Yoder result might better be justified-and might rest more comfortably with Tinker and Gault-on this principle: when the state contravenes parental decisions in child rearing with the claimed purpose of benefiting the child, the state must present a convincing case that its intervention, in fact, will serve its professed goal.

The Yoder opinion was reluctant to speak thus broadly of parental prerogatives and instead relied heavily on the "religious" aspect of the particular prerogatives claimed. Tinker and Gault ignored the parents' roles in resisting state intervention for their children and spoke instead of the children's rights as if they could be asserted without considering their parents' intent. But the principle uniting these cases may best be understood to establish a constitutional presumption in favor of parental prerogatives with respect to children. In the course of this discussion, the shortcomings of such a principle will become evident, but, as will be developed, it is a useful way-station on the road toward a general standard governing state substituteparenting activities.

A presumption favoring parents corresponds both to the social reality that state child rearing interventions are inherently difficult enterprises and to the psychological reality that an intensely intimate bonding between parent and child lays the best developmental foundation for this society's most prized personality attributes. ${ }^{35}$ Notwithstanding the Yoder opinion, however, it makes no sense to endow this parental presumption with irrebuttable force in any particular aspect of child rearing. Rather, a court should view all state claims to contravene parental desires with the same skeptical eyebut it should be prepared to sanction all interventions that satisfy its generally applicable criteria.

The proper criteria can readily be drawn from Supreme Court decisions protecting other "fundamental rights" from state intrusion-that is, has the need for the state intervention been convincingly identified, and is there a close correspondence between that need and the means proposed to satisfy that need. ${ }^{36}$ Application of such criteria would permit courts to gather data directly relevant to the purposes served by the presumption favoring parents. The presumption would be displaced only if the state could demonstrate that the psychological values achieved by close parent-child identity were, in fact, disserved in the particular dispute and that the historic inadequacies

35. See generally J. Goldstein, A. Freud, \& A. Solnit, Beyond the Best interests of the Child (1973); Levy \& Ellsworth, Legislative Reform of Child Custody Adjudication, 4 LAw \& Soc. REv. 167 (1969).

36. See Gunther, The Supreme Court, 1971 Term-Foreword: In Search of Evolving Doctrine on a Changing Court: A Model for a Newer Equal Protection, 86 HARv. L. REv. 1, 20 (1972). 
in state substitute-parenting techniques and resources were, in fact, remedied for the particular case.

Of these two standards, the second will have special bite. The first criterion is more obviously value-laden and thus can more easily be satisfied by simple assertion that a child's optimal development is endangered by parental practices. The state in Yoder did, in fact, make a plausible case on this ground. In Tinker, the case was available, but the school practice of forbidding only antiwar expression among all forms of student political activity, under pain of exclusion from school, undermined the plausibility of any assertion that the school sought to free students to think for themselves. And in Gault, the facts surrounding the alleged "obscene" telephone call were so confused that the state could not plausibly demonstrate deviation from any conceivable norm of child development. ${ }^{37}$ But with reference to both Tinker and Gault, the state could change its practices with relative ease and identify, for future children who display political slogans or obscenties, the first requisite of state intervention-that is, harm to the child from parental child rearing conduct.

But for the second criterion, what can the state say? Though the state may fervently and properly want to displace parental values, no one has a magic wand to make parents disappear from their children's thoughts and thus from their lives. The psychological professions have amply documented that "[e]fforts made to 'save' a child from his bad surroundings and to give him new standards are commonly of no avail, since it is his own parents who [sic], for good or ill, he values and with whom he is identified." 38 Frequently, as in Yoder, state demands contrary to parental wishes only place the child in an impossible bind, forcing him to choose between conflicting authorities, with no satisfactory principle for choice available to him. But unless the state can demonstrate that its proposed technique for intervention accounts for this psychological reality, there cannot be the clear correspondence between its means and ends that would justify its intervention.

The Court's action in Yoder illustrates both the child's dilemma and the Court's failure sensibly to comprehend it. This appears in the disagreement between the Court majority and Justice Douglas, who dissented on the ground that the religious freedom of the child alone-and not his parents-warranted judicial protection. Accordingly, Justice Douglas argued, the record must affirmatively show that the child's own religious views were opposed to secondary education. Only one child had testified on this score, and Justice Douglas concurred in exempting her from the state law because she "in fact testified that her own religious views are opposed to high-school education." ${ }^{39}$

37. See 387 U.S. at 5-7.

38. J. Bowlby, Child Care and the Growth of Love 80 (1965).

39. 406 U.S. at 243. 
The Court gave short shrift to this argument, asserting, in effect, that an identity of religious views between parent and child should be assumed unless the state can demonstrate that the child has "expressed desires to the contrary."40 But even this appears a grudging concession, as the Court observed that " $[\mathrm{t}] \mathrm{h}$ ere is nothing in the record or in the ordinary course of human experience to suggest that non-Amish parents generally consult with children of age 14-16 if they are placed in a church school of the parents' faith." 41

On the face of it, Justice Douglas appears a champion of the rights of children, of the view-as he puts it-drawn from Gault and Tinker that "children are 'persons' within the meaning of the Bill of Rights." 42 The Court's position, on the other hand, might appear to ignore children and espouse their parents' "chattel rights" in them. But the question is more complex than this. In fact, there is little practical difference between these positions. Both the Court and Justice Douglas demand some express opposition from children before recognizing a conflict between parent and child. But neither the Court nor Justice Douglas offers much protection to the child caught between his loyalties to and his dependence on his parents and his desires to become an adult autonomous of them.

This is a classic psychological bind of adolescence. ${ }^{43}$ Undoubtedly the different upbringing of Amish children significantly varies the timing and intensity of this bind for them as compared to adolescents in the more typical American culture. But for all children poised at adulthood, it is risky business directly to ask them whether they differ with their parents on matters crucial to both and to expect that the answer will give a reliable guide to action in the child's interest. Often the child's true feeling is deep ambivalence -and he is paralyzed into silence by that ambivalence, or he masks it with a brash assertion that he agrees or disagrees with his parents. Justice Douglas's solution may, indeed, only harmfully intensify the psychological bind for these children by forcing them publicly either to disavow their parents or to announce their acquiescence and consequent impotence in response to parental direction.

This is not to say that children of whatever age have no autonomous will. But the typical difficulty is for children clearly to identify-even to themselves -and crisply to announce their self-determination. ${ }^{44}$ Thus, both the Court and Justice Douglas were wrong to demand a clear expression of the child's

40. Id. at 231 .

41. Id. at 232 .

42. Id. at 243 .

43. See, e.g., E. ERIkson, Identity: Youth ANd Crisis 122-35 (1968).

44. To face up to one's real emotions and to probe into one's real motives is not a capacity which we expect to find in children. On the contrary, children of all ages 
view-either for or against his parents-as the first step in evaluating state claims to displace parents. The child's capacity to have an independent view is a proper goal-not the prerequisite-for state interventions. That goal can rarely, if ever, be achieved by head-on confrontation between parents and the state. It can most reliably be achieved by subtly attenuating-even disguising-the dispute, while children are quietly and progressively encouraged to be loyal to their own needs and to rely on their own definition of those needs. ${ }^{45}$

From this perspective, the best resolution of the Yoder dispute would appear to have been the compromise proposal initially advanced by the Amish but rejected by the state. A secondary school primarily catering to Amish children and limited in curricular offerings would have given state school officials a forum in which the children could be reached by outside influences that would not appear dramatically at odds with parental demands on them. As noted, this kind of compromise had been reached with Amish parents in other states.

It may be that if state school officials now proposed to compel Amish parents to send their children to such a school, the Court would retreat from the apparently blanket exemption it accorded them. But whatever the specific meaning of Yoder for future state dealings with Amish parents, that case and Tinker have contributed to forcing state school officials generally toward a subtly different attitude in responding to disputes with parents over children. Ten years ago, a parent locked in dispute with local schools was without recourse unless he could enroll his children in private school or move to a new jurisdiction. Today, that parent brings suit. Not all such suits are-or deserve to be-successful. But court actions have forced a substantial number of local schools to implement new discipline policies, to abandon hair length or school newspaper censorship regulations, to devise new testing procedures for placement in "slow learners" classes, and to adopt other significant changes in school policy. ${ }^{46}$ Thus to succeed, a parent must be adamant and willing to endure the costs, effort, and frustrations of litigation. But school officials now know that an adamant parent has a fighting chance at success in court. Whatever the conscious intent of the courts-in

have a natural tendency to deceive themselves about their motivations, to rationalize their actions, and to shy back from full awareness of their feelings, especially where conflicts of loyalty come into question.

Freud, On the Difficulties of Communicating With Children-The Lesser Children in Chambers, in The Family and the Law 261, 262 (J. Goldstein \& J. Katz eds. 1965).

45. See generally A. Aichrorn, Wayward Youth (1965); A. Freud, The Psychoanalytical Treatment of Childoren 9-10 (1964); Schafer, Generative Empathy in the Treatment Situation, 28 Psychoanalytic Q. 342, 367 (1959).

46. See, e.g., Mills v. Board of Educ., 348 F. Supp. 866 (D.D.C. 1972) (emotionally disturbed children); Hatter v. Los Angeles City High School Dist., 452 F.2d 673, 675 (9th Cir. 1969) (hair length); Pennsylvania Ass'n for Retarded Children v. Pennsylvania, 343 F. Supp. 279 (E.D. Pa. 1972) (retarded children). 
building on Tinker and the spirit of Gault-such decisions have altered the atmosphere in which school-parent disputes take place. They have set in motion an operational presumption favoring parents by putting schools on notice that they must be prepared to justify their substitute-parenting interventions to an external agency.

The substantive scope of this presumption favoring parents is not clear, which obviously troubled the Court both in Yoder and Tinker. The Yoder Court responded, as has been discussed, by attempting to limit its ruling to traditional religions and to practices that were "obviously" not harmful to children, but neither of these limits withstands close analysis. Tinker attempted to limit its reach, in part, by restricting attention to grand issues and excluding school "regulation of the length of skirts or the type of clothing . . hair style or deportment." ${ }^{47}$ It quickly became apparent, however, that many students (and their parents) did not subscribe to the Court's hierarchy of importance, and substantial numbers of lower courts have used Tinker to strike down school regulations on precisely these matters. ${ }^{48}$

But the absence of substantive clarity in this presumption favoring parents should not be troubling. In fact, doctrinal tidiness in these matters is neither possible nor desirable. State policy toward child rearing revolves around attempts to answer this question: will children become what this society most wants if parents are left to follow their own stars in child rearing and if plural subcultural groups are free to shape norms of child rearing for parents, or if the more inclusive state community is permitted to intrude and set limits on both parental and small-group impositions on children? The answer to this question surely must be that there can be no conclusive answer favoring one contestant over the other.

Though it may seem paradoxical, that answer is a central guide for court review of state child rearing policy. If there can be no such conclusive answer, courts should properly insist that the question remain adequately open. When, as in Yoder or Tinker, battle lines for resolution seem clearly drawnwhen the state is patently attempting to override individual parental or subcultural group norms for child rearing and when the latter are patently resisting-it is important to assure that none of the claimants for control conclusively ousts the others. This, after all, is the practical effect of the holdings in those cases. School officials in Yoder remain free to require elementary education for Amish children. State claims only for compulsory higher education were rejected because the Court perceived that this would fundamentally "undermin[e] the Amish community and religious practice as they exist today." 49 And in Tinker, school officials are still permitted to prescribe

47. 393 U.S. at 507-08.

48. See cases cited note 46 supra.

49. 406 U.S. at 218. 
curriculum and thus dictate in important ways what their students think about. The Court only rejected school demands to dictate what students might say about the Vietnam War.

A constitutional presumption against state substitute-parenting might appear to violate this prescription by providing that state claims should typically be defeated, no matter what. But this only appears on the face of the doctrine, in the presentational rhetoric needed to link it to the grand tradition of constitutional exegesis. In final analysis, the process of judicial intervention-the cumulated instances of judicial application of the doctrine -will itself tend to forge an appropriate accommodation of competing state and parental claims over children.

In these disputes, a number of elements must come together to bring judicial intervention. Adamant parents can enlist a trial court's-or, as will quite frequently be necessary, an appellate court's-sympathy only if they can invoke widely shared norms of child rearing and prove them by appeal to the judicial sense of community experience as enlarged by expert witnesses attesting to parental wisdom in the dispute. As judges are drawn more often into these disputes, they will undoubtedly sense what Justice Jackson observed in overturning the compulsory school flag salute for Jehovah's Witness children, that ${ }^{50}$

[school b]oards are numerous and their territorial jurisdiction often small. But small and local authority may feel less sense of responsibility to the Constitution, and agencies of publicity may be less vigilant in calling it to account. ... There are village tyrants as well as village Hampdens ....

As school litigation continues in frequency, school officials will learn what other habitual litigants know-that conviction of one's rectitude does not assure success in court. They should thus be led to temper rigid uniformity in school administration and to respond more flexibly to the demands of school clientele, if only to forestall the haphazard impact of litigation. Thus, the process itself of holding available judicial review would tend toward achieving the basic goal of the constitutional norm-to enhance diversity, to combat any imposition of monolithic, authoritarian standards on children.

\section{IV}

This discussion has implications for future impositions of constitutional norms on the juvenile court. Many have argued that state efforts through that court to aid "children in trouble" are at best quixotic and should be generally curtailed. One commentator has distilled this argument to "the basic injunction for public policy . . . : leave kids alone wherever possible." 51

50. West Virginia State Bd. of Educ. v. Barnette, 319 U.S. 624, 637-38 (1943).

51. E. Shur, Radical Nonintervention 155 (1973). 
This dictate may be interpreted in two ways. One is that the state should refuse generally to impose any direct legal constraints on children, except when they violate laws equally applicable to adults. The other interpretation is that the state should continue to support parental authority over children, but that it should abandon the substitute-parenting claims of the juvenile court. Those who argue for the abolition of the juvenile status offensesthat is, state interventions exclusively limited to children-typically do not discuss the implications. of state power supporting parents' authority over their children.

Even if juvenile status offenses were abolished, it seems likely that much of that conduct would be easily subsumed under adult-offense rubrics such as car theft, "breaking and entering," disorderly conduct, or drug possession and the like. The abolitionist proposal would appear clearly to exclude only current truancy and runaway laws from juvenile court coercive jurisdiction. ${ }^{52}$ These status offenses would appear to be the purest examples of juvenile court claims to control a child for his own welfare rather than to protect the community from some directly dangerous conduct. But if these status offenses were abolished, would some state agency retain power to force the return of children to their parents? Under current law, a parent may file a complaint that his child has fled, and that complaint, in effect, authorizes police authorities throughout the country to arrest that child and forcibly return him home. ${ }^{53}$ If this state power is retained and the state loses only the power to force-or perhaps even to offer-alternative custodial placements for the juvenile, it may be questioned whether children's interests are thus well served. It is equally questionable whether any of this state coercive authority over runaway children should be wholly abolished.

These two events, juvenile flight from parents or from school, most directly express adolescent efforts at self-definition in combat with constituted authority. ${ }^{54}$ Insofar as the state intends to assist the fleeing juvenile in resolving the developmental implications of his flight, invocation of force seems to carry greatest dangers. Whether forced back into home, school, or other arrangements, the coercion itself is likely to appear to the juvenile-and to mean, in fact-that his reasons for flight have been ignored and his autonomy overridden. But failure to exert force can have equally disheartening meaning

52. It is conceivable, however, that these status offenses (and even the more overt antisocial juvenile acts) would be reached by an expanded use of child-neglect laws, converting all adolescent aberrations into evidence of parental failures. The abolitionists will have a formidable task in cauterizing the neglect hydra.

53. See the widely adopted Interstate Compact on Juveniles, set out, for example, in CaL. WEL. \& INST'NS CODE $\$ 1300$ (West 1972). See also id. $\$ \S 600,625$ (authorizing arrest without warrant of a minor under 18 if he "has no parent or guardian or ... parent actually exercising ... care or control").

54. See E. ERIKSON, supra note 43; Suddick, Runaways: A Review of the Literature, 24 JuvenILE JUSTICE 47 (1973). 
for the juvenile. It may mean that no one has taken up his dare to prove that he is wanted. It may mean that no one will help him act on his need to return to home or school while accommodating his equally powerful need not to admit his dependence. ${ }^{55}$ There can thus be quite important reasons to retain state power to coerce in order to help some runaway children.

But the same dilemma presents itself here as in the earlier discussion of other state-parenting interventions. Though the case can be made for beneficial application of state power, how reliably beneficial can that power be in the hands of the state agencies that traditionally exercise it? There is no assured answer to this question. But in view of the developmental significance of runaway behavior and the likelihood that withholding state intervention in many cases will lead to results no one-including the juvenile -wants, it seems worth the effort to attempt more subtle mechanisms to control state power before jettisoning it altogether.

One possibility in particular appears worth exploring-that coercive invocation of state power for runaways should be retained, but be made strictly time-limited. Thus, for example, a juvenile court could command a runaway child to remain in a state-sponsored foster home for two months, but at the end of that time, the option to remain there would belong wholly to the juvenile himself. If he then decided to renew his flight, the state might have authority to invoke another coercive placement-perhaps with the juvenile's parents or another foster family, or in an institution-but these, too, would be time-limited coercions. At some time-and after the failure of some number of forced placements to engage the juvenile's voluntary adherence-there should be no more state authority to exercise added coercions solely because of the juvenile's flight.

Though the ultimate time-limit imposed would in one sense be arbitrary, since the juvenile's psychological needs for both freedom and coercion would remain unresolved, a social reality should now be superimposed on this individual diagnostic view of the juvenile's psychology. This social reality is that state coercion of children too readily becomes an end in itself rather than a means for helping troubled children. If state power over runaways is to match its claimed purpose to assist children toward greater capacity for self-determination, the state must be held rigorously to demonstrating the reality of that goal in individual cases. The state must accordingly be forced, within a relatively limited time, to obtain the willing acquiescence of the child for continued state intervention. Unless the state is forced to rely on persuasion, it will too readily rely on force. If state officials are permitted long-term indulgence of typical official fantasies that force cures all, they will have no adequate incentive to work toward enlisting the willing

55. See Nir \& Cutler, The Therapeutic Utilization of the Juvenile Court, 130 Aм. J. PSYCHIATRY 1112,1116 (1973). 
cooperation of the child, and the possibility of any beneficial purpose for him will be jeopardized. ${ }^{56}$ Further, if state officials knew that they would be forced quickly to find a place where runaway children were willing to remain, there would be incentive to relax the rigidly moralistic standards now followed by most juvenile court authorities in approving group or individual foster homes as alternative placements. Instead of imposing their definitions of "the good life" on hapless children, these state officials would now be forced to collaborate with their charges to find an acceptable accommodation.

After a runaway child had rejected every placement for which the state had time to coerce, this scheme would not leave him utterly without state protection. This child, like all adults, would be protected against others' depredations by the criminal laws proscribing assaults, rapes, narcotics dealings, and the like. In many instances, of course, these laws will not effectively protect children from harm. But it is false to think that confining children for indefinite terms does effectively protect them. Locking them away imposes different harms than would occur if they roamed freely. And when the state locks children away-whether in secure state institutions or in their parents' homes from which they persistently flee and to which police persistently return them-the harm is directly inflicted by state action. Accordingly, if state power over children is limited by some constitutional principle, the state cannot argue that the harm it inflicts is no worse than that which others might inflict.

But this raises the further question: does a constitutional principle compel some such limitation on state power over runaway children? This question is not readily answered by resort to the constitutional principle posited earlier in this discussion-that parents' disposition of children should presumptively prevail in disputes with the state. The parents of many runaway children willingly turn them over to state custody. For these children, should agreement between parents and the state justify unlimited exercise of state power over children? For other runaway children, the ștate may want to force them again and again to return to their parents from whom they persistently flee. For these children, should the state be constitutionally permitted to adhere to the parental presumption no matter how persistently the child protests?

These questions amount to this: does the principle drawn from Yoder and the other cases discussed mean that parents have a constitutionally-sanctioned role in their children's lives; or does it mean that the state has a constitutionally-limited role in child rearing that typically, but not necessarily, is enforced by deference to parents? The contrasting positions can be illus-

56. For development of this discussion and reflections on the utility of time-limited commitments in permitting a juvenile's attorney to accommodate his competing roles of advocate for and counsellor to his client, see Burt, The Therapeutic Use and Abuse of State Power Over Adolescents, in Current Issues in Adolescent Psychiatry 243 (J. Schoolar ed. 1973). 
trated by referring to the Supreme Court's 1923 decision, Meyer $v$. Nebraska, ${ }^{57}$ which the Yoder Court repeatedly invoked in its opinion. ${ }^{58}$ Meyer overturned a state law that prohibited any foreign-language instruction to elementary school children. In the course of its opinion, the Meyer Court stated: ${ }^{59}$

It is said the purpose of the legislation was to promote civic development by inhibiting training and education of the immature in foreign tongues and ideals before they could learn English and acquire American ideals; and "that the English language should be and become the mother tongue of all children reared in this State." It is also affirmed that the foreign born population is very large, that certain communities commonly use foreign words, follow foreign leaders, move in a foreign atmosphere, and that the children are thereby hindered from becoming citizens of the most useful type, and the public safety is imperiled.

That the State may do much, go very far, indeed, in order to improve the quality of its citizens, physically, mentally, and morally, is clear; but the individual has certain fundamental rights which must be respected. . . .

For the welfare of his Ideal Commonwealth, Plato suggested a law which should provide: "That the wives of our guardians are to be common ... and no parent is to know his own child, nor any child his parent. . . The proper officers will take the offspring of the good parents to the pen or fold, and there they will deposit them with certain nurses who dwell in a separate quarter; but the offspring of the inferior, or of the better when they chance to be deformed, will be put away in some mysterious, unknown place, as they should be." In order to submerge the individual and develop ideal citizens, Sparta assembled the males at seven into barracks and intrusted their subsequent education and training to official guardians. Although such measures have been deliberately approved by men of great genius, their ideas touching the relation between individual and State were wholly different from those upon which our institutions rest; and it hardly will be affirmed that any legislature could impose such restrictions upon the people of a State without doing violence to both letter and spirit of the Constitution.

This extensive quotation from Meyer does not conclusively resolve the question at issue, since the state legislation was clearly aimed at the Germanspeaking parental community. But the specific context of the case was a prosecution against a private school teacher-not a parent-who defied the statute. And the Court spoke of "the relation between individual and state" -not the relation between parent and the state-as its touchstone for limiting state power. Further, the Supreme Court decisions in Tinker-which also rested explicitly on Meyer ${ }^{60}$ _ and in Gault also spoke directly to the limits on state power over all individuals, whether child or adult. Though the Court ignored the powerful psychological role played by the parents, its disposition

57. 262 U.S. 390 (1923)

58. 406 U.S. at 205.

59. 262 U.S. at 401-02.

60. 393 U.S. at 506. 
of those cases suggests that deference to parental views was mandated not to respect them as such, but to limit state power as such "to submerge the individual and develop ideal citizens."

From this perspective, constitutional values are called into question whenever the state professes to act with children in the role traditionally taken by parents in this society. From this perspective, rigorous standards for justification should be imposed on state substitute-parenting actions, irrespective of the desires of the child's acknowledged parents. In applying those standards, the parents' acquiescence in state intervention may itself convincingly establish the need for it. But that acquiescence would not necessarily demonstrate the requisite close correspondence between the child's need and the means by which the state proposes to satisfy that need. Moreover, as Meyer and its recent progeny make clear, the state must be more limited in its claims to mold its citizens than parents in their claims. This is, simply put, because the Constitution directly limits the state, not parents.

Accordingly, in reviewing state runaway statutes, constitutional norms could properly be applied generally to require some firm limitation on the breadth of state power in order to ensure that the means of state intervention rigorously and reliably correspond to the purposes for that intervention. Consideration of state runaway statutes casts in sharp relief one facet of the constitutional analysis underlying all of the preceding discussion-that children are a subject population, no matter who exercises authority over them, and that all such authority-whether school teachers, juvenile court judges, or parents-is supported by state sanction, by legal artifact. Thus, constitutional norms limiting state child rearing activity, it would appear, must apply to all of its guises, including state support for parental authority over children.

This proposition echoes the constitutional law debates attempting to define "state action." 61 Here, as in other contexts in this debate, it is possible to argue as a matter of formal logic that every interaction between parent and child is "state action" because state support for parental authority is so pervasive. By this logic, any imposition of parental discipline might require Miranda warnings and appointment of counsel for the accused child. ${ }^{62}$ In order to avoid this strained result, however, it is not necessary in all circumstances to ignore the reality that state support for parental authority pervades child rearing policy in this society. At least when battle lines are clearly drawn between parent and child-as when the child flees home-and overt state support is invoked by the parent, it makes sense to insist that this parentallyinvoked state authority be held subject to the constitutional norms generally

61. See articles cited in G. Gunther \& $\mathrm{K}$. Dowling, Cases and Materials on Individual

Rights in Constitutional Law 454 \& n. (8th ed. 1970).

62. See Miranda v. Arizona, 384 U.S. 436 (1966). 
applicable to the police power and that the state be required to respect children's claims to developing autonomous individuality.

$\mathrm{V}$

These constitutional norms call into question any state program that relies on large-scale, geographically remote, full-time residential institutions for children, even when parents agree to such institutionalization. Constitutional challenges have been mounted, with some success, regarding conditions in these institutions-essentially to establish a "right to treatment" in them. But from the perspective proposed here, the constitutional wrong is not so much the state failure to deliver promised services as the totality of the state's claim over every aspect of the lives of children in these institutions. These institutions-whether for mentally retarded or seriously emotionally-disturbed or homeless children-are totalitarian, in both the descriptive and the pejorative senses of that word. They are quintessentially the institutions described by Plato and condemned by the Supreme Court in Meyer: "the offspring of the inferior, or of the better when they chance to be deformed, will be put away in some mysterious, unknown place, as they should be."

Among professionals in the behavioral disciplines, there is virtually unanimous condemnation of large-scale state child-caring institutions and equal support of community services to children that do not rigidly segregate them by imposing either geographic distance or pejorative labels on them. ${ }^{63}$ This critique has met powerful resistance from many sources-from legislators who are unwilling to appropriate new funds or to abandon the capital investments in mammoth existing buildings; from specialized professionals who have built their careers either in serving these "special children" or in refusing to serve them because they were not "normal"; and from parents who find relief from the burdens of their difficult children by consigning them to state institutions.

This resistance has, perhaps surprisingly, also been evident in the recent court cases positing a constitutional "right to treatment" for institutionalized children. The leading case is Wyatt $v$. Stickney, ${ }^{64}$ dealing with a remote, rural state institution in Alabama housing some five thousand retarded children in conditions of unrelieved horror. The Wyatt court was visibly shocked at the evidence and imposed elaborate remedial standards for improved living conditions, disciplinary policies, staffing ratios, record-keeping, and other aspects of institutional life. ${ }^{65}$ But Wyatt never confronted the basic question

63. See generally Handbook on Classification of Exceptional Children (N. Hobbs ed. 1974).

64. 344 F. Supp. 387 (M.D. Ala. 1972).

65. App. A, id. at 395. 
whether any large-scale, geographically remote, full-time residential institution can beneficially affect the lives of its residents.

Wyatt makes two explicit references to this question. Its standards posit that every resident is entitled to "the least restrictive conditions necessary to achieve the purposes of habilitation" and that "no borderline or mildly mentally retarded person shall be a resident of the institution." 66 But these are easily evaded generalities. "Least restrictive conditions necessary" is, on its face, a cloudy standard. Refusing admission for "borderline" children might appear to be more enforceable, but in practice, a state can let too many retarded children slip below the requisite "borderline" by simply withholding community services that would otherwise sustain and develop their capacities.

There is a further, though only implicit, pressure against institutional residence in Wyatt. The imposed standards requiring specified staffing, payment of minimum wages to residents for performing institutional maintenance tasks, and other specified institutional amenities may prove so expensive that the state will be led to close the institution. But whatever the judge or the parties might have intended, this prospect seems remote. The Wyatt standards are not carved in stone. State budgetary constraints and popular eagerness to forget retarded children are recurring realities that are likely to erode the more stringent and expensive standards over time.

Approaching the problem through the constitutional right to treatment was misleading. It permitted the court and parties to address institutional treatment resources in isolation, without forcing them to justify the very existence of this treatment modality. The Wyatt court was unwittingly drawn into the same bind that has defeated the good intentions of other state officials who attempt to assume full parenting responsibility for a narrowly defined, readily stigmatized, and vulnerable group of children. If, however, the court had insisted that the state justify maintaining this institution-insisted, that is, on a demonstration of close correspondence between the state's avowed means and ends-an effective (though costly) remedy would have been at hand.

The retardate institution does, in its present guise, efficiently accomplish one purpose-to hide from sight abnormal and frightening children. But when challenged in litigation, it is likely that most state officials would be ashamed to advertise this purpose, and courts demanding substantial justifications for state activity should give weight only to those purposes that the state officials are willing to avow. ${ }^{67}$ If state officials did admit these motives, however, the question would be clearly drawn whether contemporary courts are willing to reject the totalitarian implications of Plato's Ideal Commonwealth, as did the Supreme Court in Meyer in 1923.

66. Id. at 396 .

67. See Gunther, supra note 36 , at 35-36, 45-46. 
Plato would have "put away" deformed children without regard to parental choice. But state willingness to implement such parental choice poses the same moral issue-from the child's perspective at least-in evaluating state conduct. At base, these intrinsically and grossly dehumanizing institutions "treat members of the human race as nonhumans, as objects to be toyed with and discarded." 68 State sponsorship of these institutions constitutes social approbation of inhumanity so stunning that it approaches the evils of other institutionalized degradations at times practiced and rejected by this societythe death penalty and human slavery. ${ }^{69}$ The continued existence of geographically isolated, large-scale institutions for retarded children challenges our adherence to the democratic ethos that "the State . . . must treat its members with respect for their intrinsic worth as human beings."70

\section{VI}

Another line of recent Supreme Court cases adds support to the constitutional analysis advanced thus far. The Court has now more or less clearly ruled that the state may not fix an "illegitimacy" label to children born out of wedlock and thereby deprive either children or parents of advantages bestowed on wedlock families. ${ }^{71}$ These decisions have rested on equal protection grounds, though the Court has been uncertain in its articulation. In particular, the Court has not made clear whether it regards illegitimacy laws as utterly without rationality or whether these state laws transgress some independent social value, which, accordingly, requires the state to demonstrate some specially persuasive need for them. ${ }^{72}$

Regarding most discriminations directed against "illegitimate" children, it might seem unimportant to resolve this analytic question. It is almost preposterous to argue, for example, that state policy against casual sexual liaisons would be furthered by depriving the resultant children of insurance benefits on their mother's death. An argument could be advanced that each discrimination against illegitimates, viewed in isolation, might seem silly but that the whole pattern of state discriminations creates a useful social pressure against extramarital childbearing. But though the argument can be made, it is hard seriously to make it.

68. Furman v. Georgia, 408 U.S. 238, 272-73 (1972) (Brennan, J., concurring).

69. For further discussion of this proposition, see Burt, Beyond the Right to Treatment: Strategies for Judicial Action to Aid the Retarded, in The Mentally Retarded Citizen and the Law (M. Kindred ed. 1974); and Handbook on Classification of Exceptional Children, supra note 63. For extensive consideration of the implications of special classifications generally for "educationally handicapped" children, see Kirp, Schools as Sorters: The Constitutional and Policy Implications of Student Classification, 121 U. PA. L. REv. 705 (1973).

70. Furman v. Georgia, 408 U.S. 238, 270 (1972) (Brennan, J., concurring).

71. Weber v. Aetna Cas. \& Sur. Co., 406 U.S. 164 (1972); Levy v. Louisiana, 391 U.S. 68 (1968); Glona v. American Guar. \& Liab. Ins. Co., 391 U.S. 73 (1968).

72. See Weber v. Aetna Cas. \& Sur. Co., 406 U.S. 164, 175-76 (1972); Gunther, supra note 36, at 31-32. 
The Court was, however, recently faced with a more difficult argument in favor of a state illegitimacy law that gave no special family status to the unwed father of children following their mother's death. In Stanley $v$. Illinois, ${ }^{73}$ the state had declared the father's natural children wards of the court, although it conceded that he had not been found an unfit parent. The state argued that by its legislative definition, only the "natural mother of an illegitimate child" was a "parent," and that this legislative fiat was justified for administrative convenience because "the illegitimate child normally knows only one parent-the mother." 74 Further, the state argued, Stanley was not disabled from asserting his atypical interest in his natural children, since he could now seek to adopt them-even though he would be given no statutory priority in adoption proceedings.

The Court overturned this law, notwithstanding Chief Justice Burger's dissent on the ground that "centuries of human experience buttress [the state's] view of the realities of human conditions" that unwed fathers generally are not "dependable parents." 75 (The Chief Justice apparently found his sympathies more attuned to the claims of the Amish in Yoder than to those of Stanley.) But it is instructive, for present purposes, that the Court did not assert that the state law had no rational basis. Instead, the Court gave special importance to the fact that this state law dealt with family relationships: ${ }^{76}$

The Court has frequently emphasized the importance of the family. The rights to conceive and to raise one's children have been deemed "essential," Meyer $\%$. Nebraska . . . The integrity of the family unit has found protection in the Due Process Clause of the Fourteenth Amendment, Meyer v. Nebraska....

Accordingly, the Court ruled that all parents are entitled to an individual determination of unfitness before the state can coercively remove their children, and thus the state wrongly discriminated against Stanley. ${ }^{77}$

Stanley might be considered another instance of state-parent conflict regarding the disposition of children where the Court required deference to parental views. But in other cases, in which the children themselves challenged their illegitimacy status, the Court did not concern itself with parental desires. In fact, in the first two cases invalidating this status, the children's

73. 405 U.S. 645 (1972).

74. Id. at 653 n.5.

75. Id. at 666 .

76. Id. at 651 .

77. The Stanley Court did not make clear whether it was protecting the father's interests because he had lived with his children for most of their lives or whether his biological connection with them alone warranted protection. See id. at $646,657 \mathrm{n} .9$. Where the "psychological family" and the "biological family" differ, the child's normal development can be critically jeopardized by disregarding psychological bonds and vindicating instead the biologic parent's claims to the child. See generally J. Goldstein, A. Freud, \& A. Solnit, supra note 35. In Stanley, as in other cases discussed, the Court failed to acknowledge the possibility of conflict between a child's interest and his parents' claim in him, and the Court thus did not adequately consider the proper scope of state intervention in response to such conflict. 
parents, while alive, had failed to invoke established state procedures to "acknowledge" their illegitimate children, which would have removed the subsequent disabilities. ${ }^{78}$ Thus in these cases, parental opposition to state stigmatization of their children is at least attenuated, and these cases can readily be considered instances in which the Court addressed the permissible limits of state handling of children irrespective of parental desires.

These illegitimacy cases are not closely reasoned, and the one recent Supreme Court case ${ }^{79}$ upholding imposition of an illegitimacy disability is difficult to reconcile with the others. Because the opinions in these cases are so opaque, there are many ways that the cases can be viewed. ${ }^{80}$ But from the perspective developed in this discussion, the cases invalidating the illegitimacy status-the view most recently reaffirmed by the Court ${ }^{81}$ - can be seen to support the proposition that any state imposition of special derogatory classifications regulating parent-child relations must satisfy a heavy burden of justification.

In the illegitimacy cases, the Court demanded convincing proof that the classification accomplished the avowed beneficent purposes. Similarly, courts should skeptically examine state decisions to house specially-classified "retarded" or "dependent" children in remote, large-scale institutions. As with illegitimate children, the state cannot convincingly demonstrate that the differences between these "needy" children and others in the community are sufficiently great to warrant the extreme differences in their handling by the state or that such handling is, in any event, sufficiently likely to accomplish the state's purported beneficial purposes. ${ }^{82}$ If, however, the state complied with widely prevalent professional opinion by providing assistance for these children in ways that did not rigidly isolate them from the "normal" community, two interrelated constitutional norms would thereby be satisfied. The state would be treating these children more like others-more consistent, that is, with the command of "equal protection of the laws"-and the state would be less totalitarian, less all-consuming in its parenting of these children, giving them greater access to diverse influences beyond direct state control.

\section{VII}

This discussion has addressed many instances in which the state has assumed parenting roles-as teacher, judge, and custodian of children. Underlying these state activities is a basic historical reality. During the past

78. Levy v. Louisiana, 391 U.S. 68, 79 (1968) (Harlan, J., dissenting); Glona v. American Guar. \& Liab. Ins. Co., 391 U.S. 73, 74-75 (1968).

79. Labine v. Vincent, 401 U.S. 532 (1971).

80. See Noonan, The Family and the Supreme Court, 23 Catholic U.L. Rev. 255 (1973).

81. Weber v. Aetna Cas. \& Sur. Co., 406 U.S. 164 (1972).

82. For development of this discussion, see Burt, supra note 69. 
century or more, extended kinship and tight-knit community ties in this country have visibly attenuated, leaving nuclear families and one-parent families increasingly isolated and vulnerable. As informal supports for troubled families diminished, the need for formal social institutions to achieve these supportive purposes became apparent. But the very structure of these institutions has brought impersonality, rigidity, and stigmatization, which, in turn, has defeated their helping purposes. ${ }^{83}$

In the past decade, beginning most openly with Gault, court decisions have reflected-sometimes explicitly-the growing criticism directed at social welfare agencies. The cases discussed here, dealing with various aspects of the state's parenting activities, often appear to have been decided without crossreference. But because overriding social characteristics uniformly describe these various activities, it is not surprising that the decisions themselves cluster around the same themes and that a unifying constitutional principle can be drawn from them.

Occasionally courts have fallen into a nostalgic rhetoric, romanticizing the family and implying that modern ills wouduwuld be cured if we could returnas Chief Justice Burger put it in Yoder-to "the simple life of the early Christian era that continued in America during much of our early national life." 84 Wishful fantasies aside, however, the past cannot be undone, and the need for formal state-parenting interventions will not vanish. The harmful, selfdefeating aspects of these interventions will continue unless sensible remedies can be devised. One hopes that the courts may be enlisted in an effort to limit the grandiosity of state claims over children and, at the same time, to assure reliable assistance from state agencies. The competence of courts to dictate state child rearing policies may be questioned. But some external review is needed over the narrowly-based state bureaucracies that now act as substitute-parents in a broadening range of settings. This state activity implicates fundamental libertarian values. Courts have traditionally spoken for these values in other contexts. Our children deserve as much.

83. See generally D. Rothman, The Discovery of the Asylum: Social Order and Disorder in the NeW RePUblic (1971).

84. 406 U.S. at 210 . 